Nature. 2011 May 19; 473(7347): 326-335. doi:10.1038/nature10147.

\title{
Heart Regeneration
}

\author{
Michael A. Laflamme ${ }^{1}$ and Charles E. Murry ${ }^{1,2,3}$
}

${ }^{1}$ Department of Pathology, Center for Cardiovascular Biology, Institute for Stem Cell and Regenerative Medicine, University of Washington, Seattle WA

${ }^{2}$ Department of Bioengineering, Center for Cardiovascular Biology, Institute for Stem Cell and Regenerative Medicine, University of Washington, Seattle WA

${ }^{3}$ Department of Medicine/Cardiology, Center for Cardiovascular Biology, Institute for Stem Cell and Regenerative Medicine, University of Washington, Seattle WA

\section{Preface}

Heart failure plagues industrialized nations, killing more people than any other disease. Heart failure usually results from a deficiency of cardiomyocytes, and a robust therapy to regenerate lost myocardium could help millions of patients a year. Heart regeneration is well documented in lower vertebrates and in developing mammals. After we are born, however, human heart regeneration becomes limited. In this article, Laflamme and Murry review the innate barriers to heart regeneration, the evidence for cardiomyocyte turnover in humans, and current experimental strategies to remuscularize the injured heart using adult and pluripotent stem cells, cellular reprogramming and tissue engineering.

\section{Introduction}

Heart regeneration has been intensely investigated, and intensely controversial, for over 150 years ${ }^{1}$. In pursuit of this question the heart has been stabbed, snipped, contused, cauterized, coagulated, frozen, injected with toxins, infected and infarcted, studying species ranging from marine invertebrates to horses ${ }^{2,3}$. Why has this proven to be such a difficult challenge? The heart is clearly one of the least regenerative organs in the body, so if there is a regenerative response, it is small in comparison to that seen in many other tissues, like liver, skeletal muscle, lung, gut, bladder, bone or skin. For most investigators, the question really is about whether there is no regeneration (intrinsically difficult to prove) or regeneration at very low rates (difficult to detect, but possible with sensitive approaches).

This is more than an academic argument. Heart failure is a burgeoning public health problem, and some predict this will reach epidemic proportions as our population ages. Cardiomyocyte deficiency underlies most causes of heart failure. The human left ventricle has 2-4 billion cardiomyocytes, and a myocardial infarction can wipe out $25 \%$ of these in a few hours ${ }^{4}$. Disorders of cardiac overload like hypertension or valvular disease kill cardiomyocytes slowly over many years ${ }^{5}$, and aging is associated with loss of $\sim 1 \mathrm{~g}$ of

Address for Correspondence: Charles E. Murry, MD, PhD, University of Washington, 815 Mercer Street, Brotman Building Rm 454, Seattle, WA 98109, Phone 206-616-8685, Fax 206-897-1540, murry@u.washington.edu. 
myocardium per year in the absence of specific heart disease ${ }^{6}$. If the human heart has an innate regenerative response, even a small one, it may be possible to exploit this therapeutically and enhance the heart's function. This fundamental motivation has kept investigators pursuing rare events for more than a century.

Over the last 15 years, researchers have taken a more interventional approach to the injured heart, creating the field of cardiac repair. The ultimate goal of cardiac repair is to regenerate the myocardium after injury to prevent or treat heart failure. This interdisciplinary field draws from advances in stem cells, developmental biology, biomaterials and others areas, in an attempt to create new myocardium that is electrically and mechanically integrated into the heart. Cardiac repair has moved rapidly from studies in experimental animals into clinical trials involving thousands of patients. In the following sections, we will review the evidence for heart regeneration in animal models and humans. We discuss the status of research using adult and pluripotent stem cells for cardiac repair in experimental animals, and we explore the promises and problems of cellular reprogramming and tissue engineering. Clinical trials will be covered only briefly due to space limitations, so we refer interested readers to recent reviews on this topic ${ }^{7,8}$.

\section{Heart Regeneration in Lower Vertebrates}

Unlike humans, many lower vertebrates readily regenerate limbs, appendages and internal organs after injury. There is a long history of research in amphibian heart regeneration ${ }^{9}$; but, more recently, the zebrafish has proven to be a particularly useful model, given its substantial regenerative capacity and amenability to genetic manipulation ${ }^{10}$. As was first shown by Poss and colleagues in 2002, the zebrafish heart fully regenerates following the surgical amputation of the cardiac apex, an injury which corresponds to a loss of approximately $20 \%$ of the total ventricular mass ${ }^{10}$. In the low pressure fish heart, this large wound is effectively sealed by an initial fibrin clot, which is gradually replaced by de novo regenerated heart tissue rather than scar ${ }^{10-13}$.

Not surprisingly, this regenerative response involves a substantial amount of cardiomyocyte proliferation. Even at baseline, zebrafish cardiomyocytes show a much higher degree of cell cycle activity than their mammalian counterparts, with approximately $3 \%$ of myocytes in the compact myocardium of uninjured adult zebrafish hearts incorporating the thymidine analogue bromodeoxyuridine (BrdU) during a 7-day pulse. At two weeks following amputation of the cardiac apex, the fraction of BrdU-positive myocytes was increased tenfold, and this parameter remained as high as $20 \%$ as late as one month post-injury ${ }^{10}$.

Initial experiments suggested that undifferentiated progenitor cells were the principal source of regenerating cardiomyocytes ${ }^{11}$, but a pair of recent genetic fate mapping studies unambiguously demonstrates that preexisting committed cardiomyocytes are instead the main source ${ }^{12,13}$ (Box 1). The Poss and Izpisúa Belmonte groups independently generated transgenic zebrafish in which the cardiomyocyte-specific $\mathrm{cmcl} / 2$ promoter drives expression of tamoxifen-inducible Cre recombinase. These animals were then crossed with a reporter line, in which Cre-mediated excision of a loxP-flanked stop sequence induces constitutive GFP expression. In the offspring of this cross, all preexisting cardiomyocytes and their 
progeny can be induced to express GFP following treatment with tamoxifen. If the regenerated myocardium were derived from undifferentiated progenitor cells, the new ventricular apex should be GFP-null. Instead, both groups found the vast majority of the newly regenerated cardiomyocytes were GFP-positive ${ }^{12,13}$. Thus, heart regeneration in zebrafish is principally mediated by the proliferation of preexisting cardiomyocytes, rather than generation of new cardiomyocytes from stem cells.

\section{Box 1}

\section{Genetic Fate Mapping in Heart Regeneration}

Genetic fate mapping has proven to be an invaluable tool for dissecting the mechanisms of endogenous cardiac repair in model organisms, and a number of labs have employed an elegant strategy based on the conditional Cre-lox system, which allows both temporal and cell-type specific control of reporter expression. $\boldsymbol{a}$, Following amputation, the apex of the zebrafish heart can fully regenerate. To determine the source of the newly proliferating cardiomyocytes that underlie this regeneration, the Poss group created a zebrafish strain carrying two transgenes: one in which the cardiomyocyte-specific $\mathrm{cmcl} 2$ promoter drives expression of tamoxifen-inducible Cre recombinase, and a second transgene in which Cre recombinase-induced excision of loxP-flanked stop sequences, causing a switch from constitutive DsRed to constitutive GFP expression ${ }^{12}$. Thus, when this transgenic animal was pulsed with tamoxifen, all of its cardiomyocytes and their descendents became indelibly marked with GFP. In contrast, cardiomyogenic progenitor cells should have remained DsRed+/GFP-null, because the cardiomyocyte-specific $\mathrm{cmcl} 2$ promoter would not be active in these undifferentiated cells. If progenitors later contributed to cardiomyocyte renewal following injury, one would expect those myocytes to also be DsRed+/GFP-null. Instead, the new apical myocardium was GFP+, indicating that heart regeneration in the zebrafish results from the expansion of preexisting cardiomyocytes, not the recruitment of cardiomyogenic precursors. The Izpisúa Belmonte group independently reached the same conclusions using a similar experimental design ${ }^{13} . \boldsymbol{b}$, An analogous genetic fate mapping approach was employed by Hsieh et $\mathrm{a}^{22}$ to investigate the mechanisms of cardiac regeneration in mammalian hearts. These authors generated a double-transgenic mouse in which the cardiomyocyte-specific a-MHC promoter drives tamoxifen-inducible Cre recombinase, and Cre-mediated excision of loxP flanked stop sequences induces a switch from constitutive $\beta$ galactosidase to constitutive GFP expression. Following tamoxifen treatment, $\sim 80 \%$ of the cardiomyocytes in this animal became GFP+, while $20 \%$ remained $\beta$-galactosidase+ but GFP-null. As in the analogous zebrafish experiment, any progenitor cells should remain GFP-null following the tamoxifen pulse. During normal aging for up to 1 year post-tamoxifen, the ratio of GFP+ to $\beta$-galactosidase+ cardiomyocytes remained fixed at 80:20\%, implying no significant cardiomyocyte renewal by unlabeled progenitors.

However, following infarction, the ratio of GFP+ to $\beta$-galactosidase+ shifted to $\sim 65: 35 \%$ in the peri-infarct zone, indicating that newly differentiated cardiomyocytes ( $\beta$ galactosidase+ and GFP-null because they had not undergone Cre-mediated recombination) had been recruited from the progenitor pool. Hence, in the mouse, the 
small amount of regeneration that occurs following injury involves the cardiac induction of progenitor cells.

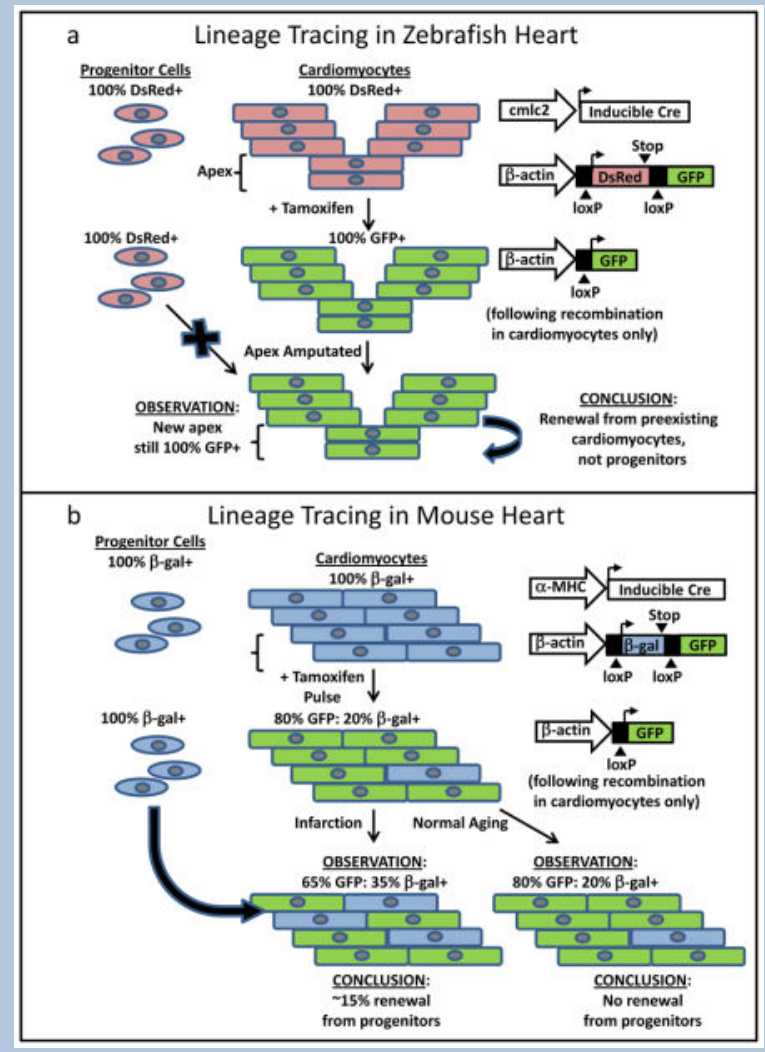

\section{Limited Regeneration in Rodent Hearts}

While lacking the remarkable regenerative capacity of the zebrafish heart, postnatal mammalian hearts also undergo some degree of cardiomyocyte renewal during both normal aging and disease. Despite all of the recent attention by the field, this is not a new concept. Extremely low but detectable levels of cardiomyocyte cell cycle activity have been reported in rodent studies dating back to the 1960 ' $^{3,14}$. Capturing the rare dividing cardiomyocytes present in mammalian hearts is technically challenging, but recent work has taken advantage of the greater specificity and throughput afforded by transgenic mouse models. For example, the Field group used transgenic mice in which the cardiomyocyte-specific a-myosin heavy chain (a-MHC) promoter drives expression of nuclear localized expression of $\beta$ galactosidase ${ }^{15}$. This convenient readout allowed them to screen $>10^{5}$ cardiomyocyte nuclei for incorporation of radiolabeled thymidine and they found labeling indices of $0.0006 \%$ and $0.0083 \%$ in adult ventricular myocytes from intact and infarcted hearts ${ }^{14,15}$.

While such proliferative indices are depressingly small, they beg the question whether such phenomena could be therapeutically augmented. Proof of concept for this approach has come from transgenic mice with cardiomyocyte-restricted overexpression of the cell-cycle activator cyclin D2, as these animals show reduced scar and improved mechanical function following myocardial infarction ${ }^{16}$. Other efforts to enhance the proliferation of adult 
cardiomyocytes by manipulating oncogenes or cell cycle regulators have proven less consistent in improving outcomes post-infarction (for a comprehensive review see ref ${ }^{17}$ ). Pharmacological enhancement of cardiomyocyte cell cycle activity would be more practical clinically than gene therapy, and the signaling molecules periostin ${ }^{18}$, fibroblast growth factor- $1^{19}$, and neuregulin- $1^{20}$ have all been reported to act as mitogens for adult ventricular myocytes and to exert beneficial effects on cardiac structure and function post-infarction. (It should be noted that a more recent study has called these effects into question in the case of periostin $^{21}$.) The Kühn group's recent study of the mitogenic effects of neuregulin-1 particularly captured the attention of the field, as they reported simple systemic injection of this factor sufficed to enhance infarct scar shrinkage and improve mechanical function ${ }^{20}$. The effect on cell cycle required intact ErbB4 receptors in cardiomyocytes and appears to stimulate mononucleated, but not binucleated, cardiomyocytes to divide. Although this intriguing result awaits independent confirmation, it suggests a straightforward approach to enhancing ventricular repair through administration of recombinant growth factors.

Most of the above studies focused on proliferation of existing cardiomyocytes, but they were not designed to detect cardiomyocytes formed from progenitor cells. To determine the whether such progenitors contribute to cardiomyocyte renewal, Hsieh et $\mathrm{al}^{22}$ performed an elegant genetic fate mapping experiment, akin to those previously described for the zebrafish model, in which cardiomyocytes were indelibly labeled following a tamoxifen pulse (Box 1). This system allowed the authors to distinguish between cardiomyocyte renewal from preexisting (and therefore fluorescently-labeled myocytes) and unlabeled progenitors. Interestingly, Hsieh et al found no significant contribution by such progenitors during normal aging (up to one year post-tamoxifen). However, they did observe a reduction in the fraction of labeled cardiomyocytes following infarction, indicating dilution by unlabeled progenitors. When combined with the findings that cardiomyocyte proliferation is vanishingly small in both normal and injured rodent hearts, these data suggest that the limited endogenous reparative mechanisms in the adult mammalian heart operate quite differently from those in zebrafish and depend more on replenishment by cardiomyogenic progenitors than myocyte proliferation.

An intriguing recent report by Sadek and colleagues ${ }^{23}$ suggests that these differences between mammalian and fish hearts do not necessarily apply earlier in development. Borrowing approaches from the zebrafish model, these authors resected the left ventricular apex of 1-day-old neonatal mice and observed a brisk regenerative response reminiscent of that in the adult zebrafish. By 3 weeks post-injury, the defect had been replaced by normal myocardial tissue, which, by 8 weeks, showed normal contractile function. Genetic fatemapping studies indicated that this regeneration was mediated by the proliferation of preexisting cardiomyocytes, again as in the zebrafish. Interestingly, this regenerative capacity was not observed in 7-day-old mice, suggesting that its loss may coincide with cardiomyocyte binucleation and reduced cell cycle activity. Nonetheless, in addition to representing a surgical tour de force, this study indicates that zebrafish-like regenerative mechanisms are latent in mammalian hearts. It also provides a new genetically tractable model for dissecting the blocks to these mechanisms in the adult. 


\section{The Evidence for Human Heart Regeneration}

Before addressing whether new cardiomyocytes are generated in the human heart after injury, it is instructive to review a few points of normal cardiac growth and adaptation to workload. These are outlined in Box 2. In brief, most human cardiomyocyte nuclei are polyploid by the onset of puberty ${ }^{24}$. In response to pathological workloads (hypertension, valve disease, post-infarction overload etc.), human cardiomyocytes commonly reinitiate DNA synthesis without nuclear division ${ }^{24,25}$. This further increases their nuclear ploidy, reaching levels as high as $64 \mathrm{C}$. Unlike rodent cardiomyocytes ${ }^{26}$, most human cardiomyocytes appear to remain mononucleated throughout life ${ }^{27}$. Thus, DNA synthesis is common in the adult human heart, but this cannot be equated with cardiomyocyte proliferation without accounting for the process of polyploidization.

\section{Box 2}

\section{Nuclear dynamics during human heart growth}

A. Fetal hearts in humans and rodents grow through proliferation of mononucleated cardiomyocytes with diploid nuclei. After birth, rodent cardiomyocytes withdraw from the cell cycle within the first few days. Human cardiomyocytes appear to proliferate for the first few months after birth, after which replication slows markedly. The cells then undergo a period of physiological growth, increasing myocyte size by $30-40$ fold. It seems that most myocytes cannot grow this much with a single diploid genome, but this problem has been solved differently in different species. Most rodent cardiomyocytes undergo a final round of DNA replication followed by nuclear division without cytokinesis, resulting in $>75 \%$ binucleated cells with a normal diploid (2C) content of DNA ${ }^{26}$. In humans and other primates, most cardiomyocytes undergo a final round of DNA replication, without nuclear division or cytokinesis, resulting in mononucleated cells ${ }^{27}$ with tetraploid (4C) or higher DNA content ${ }^{31}$. (Aficionados will note that estimates of human cardiomyocyte binucleation rates range from $25 \%$ in enzymatically dispersed fresh tissue 27 to $>60 \%$ in $\mathrm{KOH}$-digested formaldehyde-fixed tissue ${ }^{99}$. We favor the $25 \%$ value, because the harsh $\mathrm{KOH}$ digestion may selectively eliminate smaller mononucleated myocytes.) Interestingly, pacemaker cells of the sinoatrial and atrioventricular nodes remain small and diploid throughout life ${ }^{100}$. B. Cytofluorometric analysis of human cardiomyocyte nuclear DNA content as a function of myocardial weight after carefully removing valves, vessels and fat. (Hearts were grouped by weight into 4 bins for the purpose of clarity.) The percentage of diploid cardiomyocyte nuclei falls steadily as myocardial mass increases. Studies of pediatric hearts indicate that polyploidization occurs in the pre-adolescent growth phase from 8-12 years of age. Tetraploid nuclei (4C) are most common in the adult heart. During cardiac hypertrophy octaploid nuclei (8C) become most common, with a substantial number of $16 \mathrm{C}$ or higher polyploidy. These data demonstrate that human cardiomyocytes have a substantial capacity for DNA replication. Blue arrow: upper limits of normal for human myocardial weight. C. Morphometric analysis of human cardiomyocyte nuclear number during physiological and pathological growth. The normal adult number of 2 billion cardiomyocyte nuclei is reached by $\sim 2$ months age. Cardiomyocyte nuclear number 
remains steady during physiological hypertrophy, but when heart weight exceeds $\sim 450 \mathrm{~g}$ (myocardial weight $\sim 210 \mathrm{~g}$ ) there appears to be a linear increase in cardiomyocyte nuclear number with increasing cardiac mass. Since human hearts do not change nuclear number with hypertrophy, this is evidence for generation of new cardiomyocytes, either from pre-existing cardiomyocytes or from stem cells. Blue arrow: upper limits of normal for human myocardial weight. D. Non-myocyte nuclei increase linearly with increasing myocardial mass, indicating proliferation of these cells accompanies all phases of cardiac growth. Blue arrow: upper limits of normal for human myocardial weight.

The data in panels B-D are derived from Adler and Costabel ${ }^{31}$. The trend line in panel C is hand-drawn and for illustration purposes only.

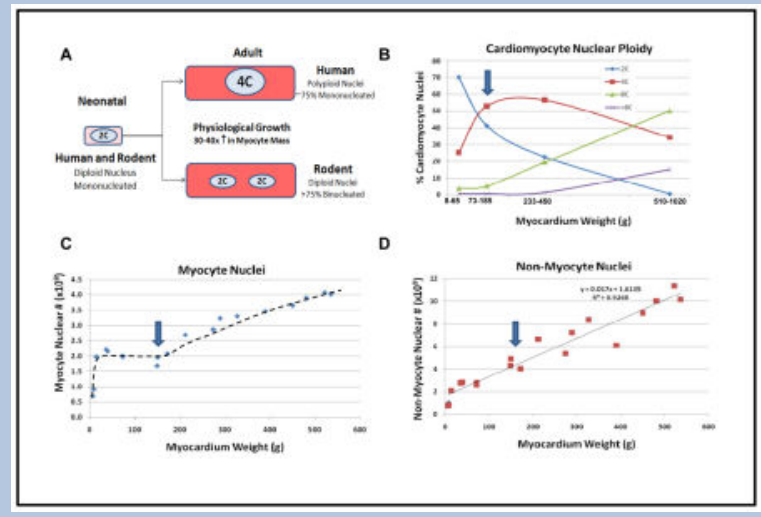

Historically, regenerative responses have been detected either by macroscopic regrowth of the tissue or by the microscopic presence of mitoses. Macroscopic regeneration of the heart clearly does not occur. Mitosis occupies only $2 \%$ of the cell cycle, so one would predict that these would be difficult to quantify meaningfully. Experiments have borne this out, with some investigators reporting no mitotic figures after injury, and others reporting rare (and potentially abnormal) mitotic figures around the injured site ${ }^{28-30}$. One factor contributing to these discrepancies has been the inherent difficulty in recognizing cardiomyocyte nuclei in conventional histological sections ${ }^{14}$. Many of the published images are persuasive for cardiomyocyte mitosis and provide important evidence that this can occur in humans. On the other hand, extrapolation to organ turnover rates from such low numbers is perilous.

A number of investigators have taken the seemingly straightforward approach of counting the number of cardiomyocytes in the human heart during normal and pathological growth. As anyone who has attempted a task like this knows, however, it is surprisingly difficult and requires multiple assumptions. Adler et al. have the most extensive body of work on this topic $24,25,31,32$. Using a combination of meticulous dissection, histopathology, biochemical measurements of tissue DNA content, and fluorescent analysis of individual nuclear DNA content, they reported that from 50-350 g, cardiomyocyte nuclear number is steady at $~ 2$ billion. Beyond that, there is a linear increase in nuclear number with increasing heart weight, reaching 4 billion nuclei in hypertrophied hearts weighing 700-900 g. Nonmyocytes (e.g. fibroblasts and vascular cells) increase linearly with heart weight throughout life. If correct, these data imply cardiomyocyte renewal occurs during pathological 
hypertrophy. An important caveat is that the assignment of cardiomyocyte vs. non-myocyte nuclear identity was based on size and morphology of isolated nuclei. Since we know that postnatal growth and pathological hypertrophy are accompanied by increases in nuclear ploidy (hence, size), it is possible that diploid myocyte nuclei in smaller hearts were mistakenly classified as non-myocyte nuclei. On the other hand, increases in cardiomyocyte nuclear number in pathological hypertrophy were also reported by others ${ }^{33}$, using histological sections where cardiomyocyte nuclei can be more readily identified.

Two studies have attempted to use more direct means to measure cardiomyocyte DNA synthesis rates in human hearts. Bergmann et al ${ }^{34}$ used a clever approach based on the worldwide pulse of ${ }^{14} \mathrm{C}$ that occurred during atmospheric testing of nuclear weapons during the Cold War. The atmospheric ${ }^{14} \mathrm{C}$ became incorporated into plants and entered the human food chain, labeling the DNA of dividing cells. After the Limited Nuclear Test Ban Treaty, atmospheric ${ }^{14} \mathrm{C}$ levels dropped rapidly. This provided pulse-chase conditions that can be used to "birth date" cells, simply by identifying when atmospheric ${ }^{14} \mathrm{C}$ levels match those of the DNA. As expected, non-myocytes in the heart were substantially younger than the patient, with $\sim 18 \%$ turnover per year and a mean age of only 4 years. Interestingly, DNA from isolated cardiomyocyte nuclei (sorted by nuclear troponin staining) also was somewhat younger than the patient, though not nearly as young as that from non-myocytes. As indicated above, before one can infer cell division, it is essential to rule out a contribution from polyploidization. To do this, the authors sorted cardiomyocyte nuclei by their DNA content, and analyzed only the subset with a diploid DNA content. The diploid cardiomyocyte nuclei also were younger than the patient, providing good evidence for cardiomyocyte division. Mathematical modeling suggested that cardiomyocyte renewal was age-dependent, with $\sim 1 \%$ of cardiomyocytes being renewed per year at age 20 , and $0.4 \%$ at age 75 . Based on these kinetics, $\sim 45 \%$ of cardiomyocytes would be predicted to be renewed over a normal human life span, while $55 \%$ would be cells persisting since birth.

Kajstura et al ${ }^{35}$ took advantage of an interesting "natural" medical experiment to study cardiac DNA synthesis rates. They examined hearts from cancer patients who were treated with the thymidine analog, iododeoxyuridine (IdU). This agent is incorporated into nascent DNA, where it sensitizes cells to radiation therapy. The IdU was given as bolus injections or multi-week infusions, and the time between treatment and death ranged from 7 days to 4.3 years. Using immunohistochemistry to detect the IdU signal and identify cardiomyocytes, they found remarkably high cardiomyocyte DNA labeling rates, ranging from $2.5 \%$ to $46 \%$. No IdU staining was found in control hearts not exposed to the radiosensitizer.

Mathematical modeling suggested that cardiomyocytes turn over at a rate of $22 \%$ per year, compared to $20 \%$ for fibroblasts and $13 \%$ for endothelial cells. Furthermore, they reported that $83 \%$ of cardiomyocyte nuclei were diploid, suggesting that this turnover reflects cell division, not increased ploidy.

It is hard to reconcile these two studies, which differ by nearly 50 -fold in their estimates of cardiomyocyte turnover. One important difference appears related to higher cardiomyocyte DNA synthesis activity in cancer patients treated with IdU. Kajstura et al reported 3-fold lower DNA synthesis rates (based on Ki-67 immunolabeling) in control hearts vs. the IdUtreated patients. Neither study adequately rules out a contribution from DNA repair, which 
can masquerade as DNA replication in these assays. This is of particular concern in cancer patients receiving radiation plus a radiosensitizer. Kajstura et al. ${ }^{35}$ suggested that only senescent cardiomyocyte nuclei contain troponin, which could bias Bergmann's turnover studies toward low proliferation. A follow up paper from Bergmann et al ${ }^{36}$ provided evidence that nearly all cardiomyocyte nuclei were identified by troponin staining, however. Additionally, Kajstura's findings contradict two well accepted principles. First, they suggest that $>80 \%$ of cardiomyocyte nuclei are diploid, whereas virtually all other investigators report these nuclei are polyploid. If so, polyploidization could underlie their high estimates of DNA synthesis. Second, they conclude that cardiomyocytes are as proliferative as nonmyocytes, whereas virtually all other investigators find orders of magnitude greater proliferation in non-myocytes. Indeed, they reported IdU incorporation by cardiomyocytes at rates $(2.5-46 \%)$ approaching those reported for the sarcomas targeted by IdU (50$70 \%)^{37}$. The heart does not proliferate like a sarcoma, so these cardiac IdU incorporation estimates must be too high.

Taken together, these human studies provide strong evidence for plasticity in the adult human heart. There is extensive morphometric evidence for DNA synthesis and an increase in cardiomyocyte number in diseased human hearts. Cardiomyocyte division or generation from progenitor cells probably occurs in the human heart, but it appears to be a very slow process.

We need better tools to study this process quantitatively, and better ways to model it, if we hope to exploit it therapeutically.

\section{Stem Cells and Cell Therapy}

Stem cell biology is one of the fastest moving areas of biomedical research, and amongst all solid organs, the heart has one of the most active regeneration research programs. The field can be conceptually organized into work involving endogenous and exogenous cells. The many exogenous cell types can be further divided into pluripotent (ESCs, iPSCs etc.) and "adult" cells of more limited potential (circulating progenitors, resident cardiac progenitors, and cells native to other tissues. Here, we will focus on cells closest to clinical trials and those for which there are the most reliable data.

\section{Cardiac Progenitor Cells (CPCs)}

Multiple investigators reported resident populations of CPCs in postnatal hearts, which were identified using a variety of approaches, including expression of surface markers like c-Kit or Sca-1 (note that Sca-1 apparently has no human ortholog), or physiological properties like the ability to efflux fluorescent dye or form multicellular spheroids (reviewed in ${ }^{38,39}$ ). Initially, it seemed there was little overlap amongst CPCs identified by these different approaches, and some scientists suggested that multiple populations of CPCs exist. More recent studies indicate shared markers among once-distinct populations or different stages of maturation in the same line of cells 40,41 , so the field may be converging.

Most extensively studied are CPCs expressing the receptor tyrosine kinase c-Kit. In the adult, c-kit is expressed by hematopoietic stem cells, mast cells and other mature circulating 
cells, telocytes (formerly known as the interstitial cells of Cajal) and thymic epithelium.

During development, c-kit is also expressed by immature endothelial cells and cardiomyocytes ${ }^{42}$. Small round cells expressing c-Kit have been identified in the perivascular compartment of the adult heart, and their abundance increases in human heart failure ${ }^{43}$. Following isolation from rat and human hearts, c-Kit+ cells have been reported to give rise to cardiomyocytes, smooth muscle cells and endothelial cells. Some studies indicate that, when transplanted, c-Kit+ cells induce large-scale regeneration of myocardial infarcts and contribute to the formation of new myocardium and vessels ${ }^{44}$, while others suggest smaller-scale regeneration ${ }^{45}$. Based on these data, a clinical trial is currently underway testing the safety and feasibility of autologous c-Kit+ cells as an adjunctive treatment for patients undergoing coronary bypass surgery (NCT00474461).

Not all studies with c-Kit CPCs gave robustly positive results. In studies with genetic readouts for lineage tracing and differentiation state, c-Kit cells from the adult heart have not been found to differentiate into cardiomyocytes in vitro or following transplantation into infarcted hearts ${ }^{46}$. Another study using transgenic reporter mice found no evidence that endogenous c-kit+ cells differentiate into cardiomyocytes, though re-expression of c-kit in pre-existing cardiomyocytes was identified ${ }^{42}$. Others point out that myocardium, like all solid tissues, contains mast cells. Mast cells are small, round cells that reside in clusters in the perivascular space, they strongly express c-Kit, and their numbers go up in failing hearts ${ }^{47}$. Studies in humans suggest that $90-100 \%$ of all of the cardiac c-Kit+ cells are actually mast cells. On the other hand, expansion in culture appears to select for c-Kit+ cells that lack mast cell markers, indicating that freshly isolated cells and cultured cells are different populations 48 .

The other CPC population in clinical trials is the so-called cardiosphere forming cell (CFCs). CFCs are isolated based on their ability to migrate out of cultured cardiac tissue fragments and form spheroids in suspension cultures ${ }^{4950}$. As one might predict, this yields a mixture of cells, some of which express stem cell markers like c-Kit, and others that appear to come from the stromal-vascular compartment. CPCs have been reported to give rise to cardiomyocytes in vitro and in vivo after transplantation and to enhance cardiac function post-infarction ${ }^{50}$. Based on these data, a clinical trial of autologous CPCs has been initiated for patients with recent myocardial infarctions (NCT00893360). The "stemness" of CPCs has recently been questioned as well, with some suggesting that these cells are principally cardiac fibroblasts and that CPC-derived cardiomyocytes are actually contaminants derived from the original tissue ${ }^{51}$.

Thus, while the study of CPCs is one of the most exciting new areas in cardiac research, it is also one of the most controversial. Most of the work has focused on cell culture and transplantation, driven by the clinical need for cardiac repair. We know almost nothing about the endogenous behavior of CPCs, however. What is the role of these cells in development, homeostasis, aging and reaction to injury? The field needs models that permit unambiguous tracing of CPC lineage and phenotype without resorting to transplantation or cell culture (e.g. Box 1). 


\section{Bone Marrow Cells}

Considerable interest in marrow-derived cells for cardiac repair was prompted by reports that hematopoietic stem cells transdifferentiated into cardiomyocytes ${ }^{52}$. Subsequent studies showed that hematopoietic stem cells do not form cardiomyocytes but rather become mature blood cells after transplantation ${ }^{53,54}$. Nevertheless, animal studies show improvements in ventricular function when hematopoietic cells are administered post-infarction, implicating paracrine signaling as the major mechanism of action.

Work with marrow-derived stromal cells (MSCs) has followed a similar trajectory. MSCs were originally reported to transdifferentiate into cardiomyocytes ${ }^{55}$ but are now thought to exert their main actions through paracrine release of cytokines ${ }^{56}$. Interestingly, most MSCs die within days to weeks after transplantation into infarcts, yet beneficial effects can be seen long term, suggesting a critical window of time post-infarction for their action. MSCs likely operate through multiple mechanisms, but considerable evidence points toward their regulation of the Wnt pathway. MSCs secrete antagonists of canonical Wnt ligands, such as secreted frizzled related protein $2^{56}$. Blocking production of Wnt angatonists limits the beneficial effects of MSCs. Hatzistergos et al. ${ }^{57}$ recently reported that administration of MSCs to pig infarcts stimulated endogenous CPCs to contribute to repair of the infarct. Further identification paracrine mediators may allow the development of simpler, cell-free treatments based on proteins or small molecules.

Clinical trials have mostly focused on delivery of bone marrow mononuclear cells via the coronary circulation. It should be emphasized that $>99.9 \%$ of bone marrow mononuclear cells are not stem cells but rather are committed, though immature, granulocytes or other hematopoietic lineages. These trials indicate that delivery of bone marrow derivatives through the coronaries is feasible and safe, but the benefits are currently modest. MSCs are also are in clinical trials (e.g. NCT00587990). There are few published results with these cells, but interestingly, Chen et al. reported one of the strongest treatment effects seen to date in cardiac repair (a 14\% improvement in ejection fraction) following the intracoronary administration of large numbers of autologous MSCs ${ }^{58}$. Hare et al. administered allogeneic MSCs intravenously to patients within 10 days of infarction, and they reported that the cells were well tolerated and were associated with decreased arrhythmias and an improvement in some indices of contractile function ${ }^{59}$.

Taken together, the best current evidence indicates that bone marrow cells do not work via directly differentiating into new cardiomyocytes. Rather, the preponderance of evidence indicates that the marrow cells elaborate signals that control the response of cells native to the myocardium, and thereby regulate healing. While many view this as a novel aspect of stem cell biology, students of pathology will recognize this that phenomenon also fits under a more familiar heading: inflammation. We find it useful to consider the participation of marrow derivatives in cardiac repair as part of the inflammatory response, which has long been known to regulate angiogenesis, cardiomyocyte survival, and left ventricular remodeling post-infarction. 


\section{Pluripotent Stem Cells}

Many adult stem cell types are unable to generate large numbers of unambiguous cardiomyocytes. This limitation does not apply to embryonic stem cells (ESCs) or their more recently developed, "man-made" counterpart, induced pluripotent stem cells (iPSCs). Since both ESCs and iPSCs can be propagated indefinitely, while still retaining the capacity to differentiate into virtually all cell types, they represent a potentially inexhaustible supply of human cardiomyocytes. Our current thinking about how cardiomyocytes arise from ESCs is shown in Figure 1. Human ESC-derived cardiomyocytes express early cardiac transcription factors (e.g. Nkx2.5), as well as the expected sarcomeric proteins, ion channels, connexins and calcium-handling proteins (Figure 2). They exhibit functional properties similar to those reported for cardiomyocytes in the developing heart, and they undergo comparable mechanisms of excitation-contraction coupling and neurohormonal signaling ${ }^{60-63}$. Human ESC-derived cardiomyocytes have been more intensively studied, but the best available data suggests that human iPSC-derived myocytes have a very similar phenotype ${ }^{64,65}$. Importantly, cardiomyocytes from either pluripotent stem cell type are immature and so lack the expression profile, morphology and function of adult ventricular myocytes.

While the cardiac potential of ESCs and iPSCs is undisputable, their unique origin and pluripotency does present a new set of challenges. ESCs are derived from the inner cell mass of preimplantation stage blastocysts ${ }^{66}$, and this contributes to the ethical controversy surrounding their use. Moreover, ESC-based therapies will be allogeneic and require immunosuppression. iPSCs were originally generated by the reprogramming of adult somatic cells (e.g. dermal fibroblasts) via the forced expression of up to four stem cellrelated transcription factors ${ }^{67-69}$. As such, their derivation does not involve the destruction of embryos, and they could potentially be used in autologous cell therapies. Nonetheless, "first-generation" iPSCs were problematic because the reprogramming factors were introduced using integrating viruses, raising concerns about neoplastic transformation. More recently, there have been a variety of refinements to iPSC generation that should reduce or eliminate this risk, including the use of episomal gene delivery, excisable transgenes, synthetic mRNA or cell-permeant recombinant proteins (see ${ }^{70}$ and references therein). Perhaps most exciting, a number of small molecules have been shown to greatly enhance the efficiency of reprogramming ${ }^{71}$, inviting speculation that iPSCs may be generated using such factors alone in the reasonably near future. Additional work will be required to more precisely define the phenotype and maturation potential of cardiomyocytes derived from iPSCs generated by these various methods.

Another concern related to the clinical application of pluripotent stem cells is their capacity to form teratomas following transplantation ${ }^{72}$. To overcome this, the field must develop methods to enrich ESC and iPSC derivatives for cardiomyocytes or other useful cell types (e.g. endothelial, smooth muscle, and stromal cells). Historically, ESCs have been differentiated via culture in three-dimensional aggregates, so-called embryoid bodies (EBs), in medium containing a high percentage of fetal calf serum. This method is poorly cardiogenic, and differentiated human EBs are typically comprised of $<1 \%$ cardiomyocytes $^{73}$. More recently, our group and others have used insights from 
developmental biology to devise better controlled approaches in which human ESCs and iPSCs are treated with defined factors, resulting in highly enriched populations of cardiomyocytes $^{74-76}$. A common theme with such protocols has been the manipulation of cardioinductive molecules belonging to the transforming growth factor- $\beta$ superfamily, specifically, activin and the bone morphogenetic proteins (BMPs). For example, our group has reported a protocol involving the serial application of activin A and BMP-4, which reliably yields $\sim 60-80 \%$ human ESC-derived cardiomyocytes in large-scale preparations $\left(\sim 10^{8-} 10^{9} \text { total cells }\right)^{74,77}$. Additional refinements are possible by manipulating the Wnt/ $\beta$ catenin signaling pathway ${ }^{78}$, which mediates biphasic effects on ESC cardiogenesis, promoting mesodermal induction early, but inhibiting cardiogenesis late ${ }^{79}$.

A complementary approach involves the isolation of mesodermal progenitors with a more restricted potential (e.g. cardiovascular progenitors able to differentiate into cardiomyocytes, smooth muscle cells, and endothelial cells). Such multipotent progenitors have been identified in differentiating ESC cultures based on their expression of transcription factors including $\mathrm{Mesp}^{80}, \mathrm{Nkx} 2.5^{81}$, and Is $11^{82,83}$. Arguably more useful for eventual clinical application are progenitor populations that can be sorted based on their expression of a cell surface marker, such as the cardiovascular progenitors marked by expression of KDR (also known as Flk-1) ${ }^{75}$. If such cells could be induced to self-renew, they would be potentially very useful for cardiac repair.

Human ESC-derived cardiomyocytes have been shown to engraft in infarcted mouse, rat, guinea pig and porcine hearts (Figure 3), forming islands of nascent, proliferating human myocardium within the scar zone $74,84,85$. This partial remuscularization was accompanied by beneficial effects on regional and global cardiac function ${ }^{74,84}$, although some investigators have questioned whether these effects are sustained at late timepoints ${ }^{86}$. An important point is that the mechanism(s) underlying the observed improvements in contractile function remain unresolved. In the aforementioned rodent studies, most of the graft tissue was isolated from the host myocardium by scar tissue, which may prevent synchronous beating. Additionally, these human cells (which fire in vitro at $\sim 50-150$ beats per minute $\left.(\mathrm{bpm})^{77}\right)$ may not keep pace with the rapid rate of rats $(\sim 400 \mathrm{bpm})$ and mice $(\sim 600 \mathrm{bpm})$. If they cannot, then the observed salutary effects likely resulted from an indirect, "paracrine" mechanism, like those described above for adult cells. On the other hand, this also implies that an additional increment of benefit is possible following transplantation in a slower-rated recipient, such as a canine or porcine infarct model.

\section{Reprogramming Fibroblasts to Cardiomyocytes}

Fifteen years ago, researchers showed that fibroblasts could be "transdifferentiated" into skeletal muscle in vitro or in the injured heart by overexpressing the myogenic transcription factor, MyoD ${ }^{87}$. Despite an intensive search by multiple groups, no comparable "master gene" for cardiac muscle was found, and interest in reprogramming waned. Spurred by the discovery of iPSCs, scientists have returned to this field, this time using combinations of transcription factors to reactivate core transcriptional networks of desired cell types. In an attempt to induce cardiac differentiation, Ieda, Srivastava et al ${ }^{88}$ systematically screened 14 cardiac transcription factors for their ability to activate a cardiac-specific transgene ( $a$ - 
myosin heavy chain promoter driving YFP) in cardiac fibroblasts. The full cocktail activated fluorescence in $\sim 1 \%$ of cells. A systematic winnowing yielded three transcription factors (Mef2C, Gata4 and Tbx5) that activated the transgene in $20 \%$ of fibroblasts. About $4 \%$ of the cells expressed endogenous sarcomeric proteins like cardiac troponin $\mathrm{T}$, and only $\sim 1 \%$ showed functional properties like spontaneous beating. Thus, most of the YFP+ cells were only partially reprogrammed, although their global gene expression patterns had shifted markedly from fibroblast toward cardiomyocyte.

While this manuscript was under review, Efe et al ${ }^{89}$ reported a different method of reprogramming mouse embryonic fibroblasts into cardiomyocytes. This group used the socalled Yamanaka factors (Oct-4, Sox2, Klf4 and c-Myc) to initiate reprogramming, but they blocked signaling through the JAK-STAT pathway, which is required for pluripotency in the mouse, and added the cardiogenic factor BMP-4. These modifications yielded minimal generation of iPSCs, but instead activated the cardiac progenitor program and, within 2 weeks, substantial numbers of beating colonies. They reported $\sim 40 \%$ of cells expressing cardiac troponin $\mathrm{T}$ by 18 days post-induction. The authors attributed their increased efficiency versus that of Ieda et al to the generation of highly proliferative progenitor cells, as opposed to forming cardiomyocytes with low proliferative potential. It should also be noted that Efe et al used mouse embryonic fibroblasts, while Ieda et al principally studied postnatal cardiac fibroblasts.

Reprogramming the scar-forming fibroblast to a cardiomyocyte is intuitively appealing, particularly if it can be done directly in the infarct. In order to succeed clinically, we will need to know how normal these reprogrammed cardiomyocytes are, and the process will need to be much more efficient and transgene-free. Despite some challenges, this is an exciting new avenue of research and could be a game-changer.

\section{Tissue engineering}

Tissue engineering refers to growth of 3-dimensional tissues in vitro, with goals of building more biologically relevant models for in vitro study, or building tissues for in vivo regenerative therapy. Most commonly this involves the use of porous, biodegradable scaffolds onto which cells are seeded, but other approaches include casting cells into hydrogels or creating scaffold-free tissues composed only of cells and the matrix they secrete. Synthetic materials have big advantages in manufacturability, typically being easy, cheap and reproducible. Synthetics generally have worse biocompatibility, however, because they cause foreign body inflammatory reactions and, sometimes, release locally toxic degradation products. Bioreactors are often employed in tissue engineering, providing electrical and mechanical conditioning or for delivering nutrients to the tissue via perfusion systems

A major goal in bioengineering is to improve the host response to biomaterials, in essence, to make materials that heal ${ }^{90}$. Surprisingly, the chemical composition of a material does not have a major influence on how the body responds to it. Whether materials are organic or metallic, hydrophobic or hydrophilic, or positively or negatively charged, they all cause similar foreign body reactions. Instead, what the body seems to sense is the surface

Nature. Author manuscript; available in PMC 2014 July 10. 
topography of a material ${ }^{90}$. When surfaces are smooth, there is intense inflammation and scarring, creating a fibrotic capsule around the implant. If a surface is given a more complex topography, e.g. by creating pores or grooves, there is less inflammation, scarring diminishes and blood vessels grow into the implant. Systematic variation in the topology can "tune" this host response. For example, our tissue engineering group has developed scaffolds with two compartments: cylindrical channels to generate cables of cardiomyocytes, surrounded a network of smaller interconnected pores for stromal and vascular ingrowth ${ }^{91}$. Pores are optimally sized to maximize vascularization within the implant and minimize fibrosis around it.

The cardiomyocytes used in tissue engineering have been immature cells derived from young animals or stem cells. In order to take on an adult workload, these cells will need to organize into the cable-like structure of myocardium and hypertrophy more than ten-fold. There is an ongoing debate in tissue engineering whether this maturation should take place before or after transplantation. On the one hand, electrical ${ }^{92}$ and mechanical ${ }^{93}$ stimulation in vitro enhance hypertrophy, alignment and electromechanical function of rat cardiomyocyte constructs. On the other hand, greater cell differentiation is associated with worsened survival after transplantation ${ }^{94}$, so there is likely a point of diminishing returns. This needs to be explored more experimentally.

One of the big lessons from tissue engineering has come from studies comparing myocyteonly versus mixed-cell constructs (Figure 4). When myocyte-only constructs are transplanted, the tissue survives poorly. When vascular endothelial cells and a stromal cell population are included, the endothelial cells form networks resembling a primitive vascular plexus, and the stromal cells elaborate a provisional matrix that enhances mechanical integrity 95,96 . Upon transplantation, the endothelial network organizes into a definitive vascular network that connects to the host circulation, bringing blood flow into the tissue several days sooner than would otherwise be seen. Indeed, our group and others have demonstrated markedly improved survivability of "pre-vascularized" human myocardial constructs incorporating vascular and stromal elements over those with cardiomyocytes alone 95,97 . This indicates there is there is considerable synergy to including vessels and connective tissue elements when engineering tissue.

Tissue engineering has not been as extensively studied as cell transplantation in preclinical disease models, but initial studies are promising. Zimmermann et al. ${ }^{93}$ prepared constructs of engineered heart tissue from neonatal cardiomyocytes and conditioned these for several days using a cyclic stretch system. The constructs were sutured to the surface of rat hearts that had been infarcted two weeks previously, and they were studied one month after implantation. Hearts receiving the engineered heart tissue had better contractile function, and interestingly, conduction velocities across the infarct were improved, likely because the grafts had electrically connected to the surrounding viable myocardium. Another group reported that patches generated from cardiosphere-derived CPCs can enhance heart function post-infarction ${ }^{98}$, and there are hints that tissue engineering affords larger graft size as well. 


\section{Summary and Closing Comments}

After more than a decade of furious activity, the science of stem cells appears to be catching up with its promise. Clinical scale preparations of the main cardiac cell types can now be generated, and we are learning the rules of building myocardium and keeping it alive after transplantation. Clinical trials have established techniques for cell delivery, and protocols for establishing feasibility, safety and early stage efficacy in humans are in place. The first patient trials have demonstrated safety with hints of efficacy. So far, so good.

That said, many short and long term challenges remain. In the near term, it will be important to derive the right subtype of cardiomyocyte, for example, ventricular myocytes for repair of an infarction that are free of pacemaker cells. The major challenge facing the adult CPC field is developing protocols with higher yields of definitive cardiomyocytes. Researchers studying pluripotent stem cells need to identify the optimal stage of differentiation and demonstrate that these cells can be used without tumorigenesis. The question of allogeneic vs. autologous cells remains open. While desirable, autologous cells will be more expensive, more variable, and the time needed to expand them precludes their use in any acute setting. Allogeneic cells will provide the only "off the shelf" product, but we need to learn how best to manage the immune response to prevent their rejection. All of these efforts will be advanced by improvements in integration of the graft, including control of vascularization (growth of both arterial conduits and microvasculature), inflammation and scarring.

Further ahead, in situ manipulation of cells within the heart may allow us to control their fates, thereby obviating transplantation. For example, can CPCs be controlled with small molecules or growth factors to enhance their regenerative abilities? Can fibroblasts in infarcts be reprogrammed directly into cardiomyocytes? Given our increasing ability to control the fates of cells and tissues, the debate over whether the heart is intrinsically "terminally differentiated" seems anachronistic, for our hearts do not exist apart from the people who know how to manipulate them. It is more useful to ask what we can do to best promote cardiac regeneration, and then do it.

\section{Acknowledgments}

We thank our many colleagues whose useful discussions and work contributed to the material presented here. This work was supported by grants from the US National Institutes of Health.

\section{References}

1. Carvalho AB, de Carvalho AC. Heart regeneration: Past, present and future. World J Cardiol. 2010; 2(5):107-111. [PubMed: 21160711]

2. Rumyantsev, PP. Muscle Regeneration. Mauro, A., editor. Raven Press; New York: 1979. p. 335-355.

3. Rumyantsev, PP. Growth and hyperplasia of cardiac muscle cells. Harwood Academic Publishers; 1991.

4. Murry CE, Reinecke H, Pabon LM. Regeneration gaps: observations on stem cells and cardiac repair. J Am Coll Cardiol. 2006; 47(9):1777-1785. [PubMed: 16682301]

5. Whelan RS, Kaplinskiy V, Kitsis RN. Cell death in the pathogenesis of heart disease: mechanisms and significance. Annu Rev Physiol. 2010; 72:19-44. [PubMed: 20148665] 
6. Olivetti G, Melissari M, Capasso JM, Anversa P. Cardiomyopathy of the aging human heart. Myocyte loss and reactive cellular hypertrophy. Circ Res. 1991; 68(6):1560-1568. [PubMed: 2036710]

7. Laflamme MA, Zbinden S, Epstein SE, Murry CE. Cell-Based Therapy for Myocardial Ischemia and Infarction: Pathophysiological Mechanisms. Annu Rev Pathol. 2007; 2:307-339. [PubMed: 18039102]

8. Povsic TJ, O'Connor CM. Cell therapy for heart failure: the need for a new therapeutic strategy. Expert Rev Cardiovasc Ther. 2010; 8(8):1107-1126. [PubMed: 20670189]

9. Oberpriller JO, Oberpriller JC. Response of the adult newt ventricle to injury. J Exp Zool. 1974; 187(2):249-253. [PubMed: 4813417]

10. Poss KD, Wilson LG, Keating MT. Heart regeneration in zebrafish. Science. 2002; 298(5601): 2188-2190. [PubMed: 12481136]

11. Lepilina A, Coon AN, Kikuchi K, Holdway JE, Roberts RW, Burns CG, Poss KD. A dynamic epicardial injury response supports progenitor cell activity during zebrafish heart regeneration. Cell. 2006; 127(3):607-619. [PubMed: 17081981]

12. Kikuchi K, Holdway JE, Werdich AA, Anderson RM, Fang Y, Egnaczyk GF, Evans T, Macrae CA, Stainier DY, Poss KD. Primary contribution to zebrafish heart regeneration by gata4(+) cardiomyocytes. Nature. 2010; 464(7288):601-605. [PubMed: 20336144]

13. Jopling C, Sleep E, Raya M, Marti M, Raya A, Belmonte JC. Zebrafish heart regeneration occurs by cardiomyocyte dedifferentiation and proliferation. Nature. 2010; 464(7288):606-609. This study, and reference 12 , demonstrated that heart regeneration in zebrafish is mediated by the proliferation of preexisting cardiomyocytes, not mobilization of undifferentiated precursors. [PubMed: 20336145]

14. Soonpaa MH, Field LJ. Survey of studies examining mammalian cardiomyocyte DNA synthesis. Circ Res. 1998; 83(1):15-26. [PubMed: 9670914]

15. Soonpaa MH, Field LJ. Assessment of cardiomyocyte DNA synthesis in normal and injured adult mouse hearts. Am J Physiol. 1997; 272(1 Pt 2):H220-226. [PubMed: 9038941]

16. Hassink RJ, Pasumarthi KB, Nakajima H, Rubart M, Soonpaa MH, de la Riviere AB, Doevendans PA, Field LJ. Cardiomyocyte cell cycle activation improves cardiac function after myocardial infarction. Cardiovasc Res. 2008; 78(1):18-25. [PubMed: 18079102]

17. Ahuja P, Sdek P, MacLellan WR. Cardiac myocyte cell cycle control in development, disease, and regeneration. Physiol Rev. 2007; 87(2):521-544. [PubMed: 17429040]

18. Kuhn B, del Monte F, Hajjar RJ, Chang YS, Lebeche D, Arab S, Keating MT. Periostin induces proliferation of differentiated cardiomyocytes and promotes cardiac repair. Nat Med. 2007; 13(8): 962-969. [PubMed: 17632525]

19. Engel FB, Hsieh PC, Lee RT, Keating MT. FGF1/p38 MAP kinase inhibitor therapy induces cardiomyocyte mitosis, reduces scarring, and rescues function after myocardial infarction. Proc Natl Acad Sci U S A. 2006; 103(42):15546-15551. [PubMed: 17032753]

20. Bersell K, Arab S, Haring B, Kuhn B. Neuregulin1/ErbB4 signaling induces cardiomyocyte proliferation and repair of heart injury. Cell. 2009; 138(2):257-270. This study identified neuregulin as mitogen for cardiomyocytes and showed that its systemic administration improved function in infarcted mouse hearts. [PubMed: 19632177]

21. Lorts A, Schwanekamp JA, Elrod JW, Sargent MA, Molkentin JD. Genetic manipulation of periostin expression in the heart does not affect myocyte content, cell cycle activity, or cardiac repair. Circ Res. 2009; 104(1):e1-7. [PubMed: 19038863]

22. Hsieh PC, Segers VF, Davis ME, MacGillivray C, Gannon J, Molkentin JD, Robbins J, Lee RT. Evidence from a genetic fate-mapping study that stem cells refresh adult mammalian cardiomyocytes after injury. Nat Med. 2007; 13(8):970-974. These authors used transgenic mice and a genetic fate mapping strategy to show that progenitor cells contribute to cardiomyocyte renewal following injury. [PubMed: 17660827]

23. Porrello ER, Mahmoud AI, Simpson E, Hill JA, Richardson JA, Olson EN, Sadek HA. Transient regenerative potential of the neonatal mouse heart. Science. 2011; 331(6020):1078-1080. [PubMed: 21350179] 
24. Adler CP. Relationship between deoxyribonucleic acid content and nucleoli in human heart muscle cells and estimation of cell number during cardiac growth and hyperfunction. Recent Advances in Studies on Cardiac Structure and Metabolism. 1975; 8:373-386. A classic study, compiling data from multiple German language publications, wherein the authors used careful biochemical and cytophotometric techniques to determine cardiomyocyte number and DNA content in human hearts during normal aging and disease. [PubMed: 129834]

25. Adler CP, Friedburg H. Myocardial DNA content, ploidy level and cell number in geriatric hearts: post-mortem examinations of human myocardium in old age. J Mol Cell Cardiol. 1986; 18(1):39_ 53. [PubMed: 3950970]

26. Li F, Wang X, Capasso JM, Gerdes AM. Rapid transition of cardiac myocytes from hyperplasia to hypertrophy during postnatal development. J Mol Cell Cardiol. 1996; 28(8):1737-1746. [PubMed: 8877783]

27. Olivetti G, Cigola E, Maestri R, Corradi D, Lagrasta C, Gambert SR, Anversa P. Aging, cardiac hypertrophy and ischemic cardiomyopathy do not affect the proportion of mononucleated and multinucleated myocytes in the human heart. J Mol Cell Cardiol. 1996; 28(7):1463-1477. [PubMed: 8841934]

28. MacMahon HE. Hyperplasia and regeneration of the myocardium in infants and in children. Am $\mathbf{J}$ Pathol. 1937; 13:845-854. [PubMed: 19970351]

29. Beltrami AP, Urbanek K, Kajstura J, Yan SM, Finato N, Bussani R, Nadal-Ginard B, Silvestri F, Leri A, Beltrami CA, Anversa P. Evidence that human cardiac myocytes divide after myocardial infarction. N Engl J Med. 2001; 344(23):1750-1757. [PubMed: 11396441]

30. Rumyantsev, PP. Growth and hyperplasia of cardiac muscle cells. Carlson, BM., editor. Harwood Academic Publishers; New York: 1991. p. 210-238.

31. Adler CP, Costabel U. Cell number in human heart in atrophy, hypertrophy, and under the influence of cytostatics. Recent Advances in Studies on Cardiac Structure and Metabolism. 1975; 6:343-355. [PubMed: 128080]

32. Herget GW, Neuburger M, Plagwitz R, Adler CP. DNA content, ploidy level and number of nuclei in the human heart after myocardial infarction. Cardiovasc Res. 1997; 36(1):45-51. [PubMed: 9415271]

33. Grajek S, Lesiak M, Pyda M, Zajac M, Paradowski S, Kaczmarek E. Hypertrophy or hyperplasia in cardiac muscle. Post-mortem human morphometric study. Eur Heart J. 1993; 14(1):40-47. [PubMed: 8432290]

34. Bergmann O, Bhardwaj RD, Bernard S, Zdunek S, Barnabe-Heider F, Walsh S, Zupicich J, Alkass K, Buchholz BA, Druid H, Jovinge S, Frisen J. Evidence for cardiomyocyte renewal in humans. Science. 2009; 324(5923):98-102. In this study, the authors took advantage of the global pulse of ${ }^{14} \mathrm{C}$ during the Cold War and estimated a rate of cardiomyocyte renewal in human hearts of up to $1 \%$ per year. [PubMed: 19342590]

35. Kajstura J, Urbanek K, Perl S, Hosoda T, Zheng H, Ogorek B, Ferreira-Martins J, Goichberg P, Rondon-Clavo C, Sanada F, D’ Amario D, Rota M, Del Monte F, Orlic D, Tisdale J, Leri A, Anversa P. Cardiomyogenesis in the adult human heart. Circ Res. 2010; 107(2):305-315. [PubMed: 20522802]

36. Bergmann O, Zdunek S, Alkass K, Druid H, Bernard S, Frisen J. Identification of cardiomyocyte nuclei and assessment of ploidy for the analysis of cell turnover. Exp Cell Res. 2010; 317(2):188194. [PubMed: 20828558]

37. Kinsella TJ, Russo A, Mitchell JB, Rowland J, Jenkins J, Schwade J, Myers CE, Collins JM, Speyer J, Kornblith P, et al. A Phase I study of intermittent intravenous bromodeoxyuridine (BUdR) with conventional fractionated irradiation. Int J Radiat Oncol Biol Phys. 1984; 10(1):6976. [PubMed: 6321412]

38. Segers VF, Lee RT. Stem-cell therapy for cardiac disease. Nature. 2008; 451(7181):937-942. [PubMed: 18288183]

39. Passier R, van Laake LW, Mummery CL. Stem-cell-based therapy and lessons from the heart. Nature. 2008; 453(7193):322-329. [PubMed: 18480813] 
40. Smith RR, Barile L, Cho HC, Leppo MK, Hare JM, Messina E, Giacomello A, Abraham MR, Marban E. Regenerative potential of cardiosphere-derived cells expanded from percutaneous endomyocardial biopsy specimens. Circulation. 2007; 115(7):896-908. [PubMed: 17283259]

41. Pfister O, Oikonomopoulos A, Sereti KI, Sohn RL, Cullen D, Fine GC, Mouquet F, Westerman K, Liao R. Role of the ATP-binding cassette transporter Abcg2 in the phenotype and function of cardiac side population cells. Circ Res. 2008; 103(8):825-835. [PubMed: 18787193]

42. Tallini YN, Greene KS, Craven M, Spealman A, Breitbach M, Smith J, Fisher PJ, Steffey M, Hesse M, Doran RM, Woods A, Singh B, Yen A, Fleischmann BK, Kotlikoff MI. c-kit expression identifies cardiovascular precursors in the neonatal heart. Proc Natl Acad Sci U S A. 2009; 106(6): 1808-1813. [PubMed: 19193854]

43. Kubo H, Jaleel N, Kumarapeli A, Berretta RM, Bratinov G, Shan X, Wang H, Houser SR, Margulies KB. Increased cardiac myocyte progenitors in failing human hearts. Circulation. 2008; 118(6):649-657. [PubMed: 18645055]

44. Bearzi C, Rota M, Hosoda T, Tillmanns J, Nascimbene A, De Angelis A, Yasuzawa-Amano S, Trofimova I, Siggins RW, Lecapitaine N, Cascapera S, Beltrami AP, D’Alessandro DA, Zias E, Quaini F, Urbanek K, Michler RE, Bolli R, Kajstura J, Leri A, Anversa P. Human cardiac stem cells. Proc Natl Acad Sci U S A. 2007; 104(35):14068-14073. In this study, the authors described the isolation of c-kit positive cardiac progenitor cells from human hearts and reported their differentiation into cardiomyocytes and vascular elements both in vitro and following transplantation. [PubMed: 17709737]

45. Tang XL, Rokosh G, Sanganalmath SK, Yuan F, Sato H, Mu J, Dai S, Li C, Chen N, Peng Y, Dawn B, Hunt G, Leri A, Kajstura J, Tiwari S, Shirk G, Anversa P, Bolli R. Intracoronary administration of cardiac progenitor cells alleviates left ventricular dysfunction in rats with a 30day-old infarction. Circulation. 2010; 121(2):293-305. [PubMed: 20048209]

46. Zaruba MM, Soonpaa M, Reuter S, Field LJ. Cardiomyogenic potential of C-kit(+)-expressing cells derived from neonatal and adult mouse hearts. Circulation. 2010; 121(18):1992-2000. [PubMed: 20421520]

47. Patella V, Marino I, Arbustini E, Lamparter-Schummert B, Verga L, Adt M, Marone G. Stem cell factor in mast cells and increased mast cell density in idiopathic and ischemic cardiomyopathy. Circulation. 1998; 97(10):971-978. [PubMed: 9529265]

48. Sandstedt J, Jonsson M, Lindahl A, Jeppsson A, Asp J. C-kit+ CD45- cells found in the adult human heart represent a population of endothelial progenitor cells. Basic Res Cardiol. 2010; 105(4):545-556. [PubMed: 20119835]

49. Messina E, De Angelis L, Frati G, Morrone S, Chimenti S, Fiordaliso F, Salio M, Battaglia M, Latronico MV, Coletta M, Vivarelli E, Frati L, Cossu G, Giacomello A. Isolation and expansion of adult cardiac stem cells from human and murine heart. Circ Res. 2004; 95(9):911-921. [PubMed: 15472116]

50. Chimenti I, Smith RR, Li TS, Gerstenblith G, Messina E, Giacomello A, Marban E. Relative roles of direct regeneration versus paracrine effects of human cardiosphere-derived cells transplanted into infarcted mice. Circ Res. 2010; 106(5):971-980. [PubMed: 20110532]

51. Andersen DC, Andersen P, Schneider M, Jensen HB, Sheikh SP. Murine "cardiospheres" are not a source of stem cells with cardiomyogenic potential. Stem Cells. 2009; 27(7):1571-1581. [PubMed: 19544463]

52. Orlic D, Kajstura J, Chimenti S, Jakoniuk I, Anderson SM, Li B, Pickel J, McKay R, Nadal-Ginard B, Bodine DM, Leri A, Anversa P. Bone marrow cells regenerate infarcted myocardium. Nature. 2001; 410(6829):701-705. [PubMed: 11287958]

53. Murry CE, Soonpaa MH, Reinecke H, Nakajima H, Nakajima HO, Rubart M, Pasumarthi KB, Ismail Virag J, Bartelmez SH, Poppa V, Bradford G, Dowell JD, Williams DA, Field LJ. Haematopoietic stem cells do not transdifferentiate into cardiac myocytes in myocardial infarcts. Nature. 2004

54. Balsam LB, Wagers AJ, Christensen JL, Kofidis T, Weissman IL, Robbins RC. Haematopoietic stem cells adopt mature haematopoietic fates in ischaemic myocardium. Nature. 2004; 428(6983): 668-673. [PubMed: 15034594] 
55. Toma C, Pittenger MF, Cahill KS, Byrne BJ, Kessler PD. Human mesenchymal stem cells differentiate to a cardiomyocyte phenotype in the adult murine heart. Circulation. 2002; 105(1): 93-98. [PubMed: 11772882]

56. Mirotsou M, Zhang Z, Deb A, Zhang L, Gnecchi M, Noiseux N, Mu H, Pachori A, Dzau V. Secreted frizzled related protein 2 (Sfrp2) is the key Akt-mesenchymal stem cell-released paracrine factor mediating myocardial survival and repair. Proc Natl Acad Sci U S A. 2007; 104(5):1643-1648. [PubMed: 17251350]

57. Hatzistergos KE, Quevedo H, Oskouei BN, Hu Q, Feigenbaum GS, Margitich IS, Mazhari R, Boyle AJ, Zambrano JP, Rodriguez JE, Dulce R, Pattany PM, Valdes D, Revilla C, Heldman AW, McNiece I, Hare JM. Bone marrow mesenchymal stem cells stimulate cardiac stem cell proliferation and differentiation. Circ Res. 2010; 107(7):913-922. [PubMed: 20671238]

58. Chen SL, Fang WW, Ye F, Liu YH, Qian J, Shan SJ, Zhang JJ, Chunhua RZ, Liao LM, Lin S, Sun JP. Effect on left ventricular function of intracoronary transplantation of autologous bone marrow mesenchymal stem cell in patients with acute myocardial infarction. Am J Cardiol. 2004; 94(1): 92-95. [PubMed: 15219514]

59. Hare JM, Traverse JH, Henry TD, Dib N, Strumpf RK, Schulman SP, Gerstenblith G, DeMaria AN, Denktas AE, Gammon RS, Hermiller JB Jr, Reisman MA, Schaer GL, Sherman W. A randomized double-blind placebo-controlled dose-escalation study of intravenous adult human mesenchymal stem cells (prochymal) after acute myocardial infarction. J Am Coll Cardiol. 2009; 54(24):2277-2286. [PubMed: 19958962]

60. Kehat I, Kenyagin-Karsenti D, Snir M, Segev H, Amit M, Gepstein A, Livne E, Binah O, Itskovitz-Eldor J, Gepstein L. Human embryonic stem cells can differentiate into myocytes with structural and functional properties of cardiomyocytes. J Clin Invest. 2001; 108(3):407-414. [PubMed: 11489934]

61. Sartiani L, Bettiol E, Stillitano F, Mugelli A, Cerbai E, Jaconi ME. Developmental changes in cardiomyocytes differentiated from human embryonic stem cells: a molecular and electrophysiological approach. Stem Cells. 2007; 25(5):1136-1144. [PubMed: 17255522]

62. He JQ, Ma Y, Lee Y, Thomson JA, Kamp TJ. Human embryonic stem cells develop into multiple types of cardiac myocytes: action potential characterization. Circ Res. 2003; 93(1):32-39. [PubMed: 12791707]

63. Zhu WZ, Santana LF, Laflamme MA. Local control of excitation-contraction coupling in human embryonic stem cell-derived cardiomyocytes. PLoS ONE. 2009; 4(4):e5407. [PubMed: 19404384]

64. Zhang J, Wilson GF, Soerens AG, Koonce CH, Yu J, Palecek SP, Thomson JA, Kamp TJ. Functional cardiomyocytes derived from human induced pluripotent stem cells. Circ Res. 2009; 104(4):e30-41. [PubMed: 19213953]

65. Zwi L, Caspi O, Arbel G, Huber I, Gepstein A, Park IH, Gepstein L. Cardiomyocyte differentiation of human induced pluripotent stem cells. Circulation. 2009; 120(15):1513-1523. [PubMed: 19786631]

66. Thomson JA, Itskovitz-Eldor J, Shapiro SS, Waknitz MA, Swiergiel JJ, Marshall VS, Jones JM. Embryonic stem cell lines derived from human blastocysts. Science. 1998; 282(5391):1145-1147. [PubMed: 9804556]

67. Takahashi K, Tanabe K, Ohnuki M, Narita M, Ichisaka T, Tomoda K, Yamanaka S. Induction of pluripotent stem cells from adult human fibroblasts by defined factors. Cell. 2007; 131(5):861872. [PubMed: 18035408]

68. Takahashi K, Yamanaka S. Induction of pluripotent stem cells from mouse embryonic and adult fibroblast cultures by defined factors. Cell. 2006; 126(4):663-676. [PubMed: 16904174]

69. Yu J, Vodyanik MA, Smuga-Otto K, Antosiewicz-Bourget J, Frane JL, Tian S, Nie J, Jonsdottir GA, Ruotti V, Stewart R, Slukvin II, Thomson JA. Induced pluripotent stem cell lines derived from human somatic cells. Science. 2007; 318(5858):1917-1920. [PubMed: 18029452]

70. Warren L, Manos PD, Ahfeldt T, Loh YH, Li H, Lau F, Ebina W, Mandal PK, Smith ZD, Meissner A, Daley GQ, Brack AS, Collins JJ, Cowan C, Schlaeger TM, Rossi DJ. Highly efficient reprogramming to pluripotency and directed differentiation of human cells with synthetic modified mRNA. Cell Stem Cell. 2010; 7(5):618-630. [PubMed: 20888316] 
71. Shi Y, Desponts C, Do JT, Hahm HS, Scholer HR, Ding S. Induction of pluripotent stem cells from mouse embryonic fibroblasts by Oct 4 and Klf4 with small-molecule compounds. Cell Stem Cell. 2008; 3(5):568-574. [PubMed: 18983970]

72. Nussbaum J, Minami E, Laflamme MA, Virag JA, Ware CB, Masino A, Muskheli V, Pabon L, Reinecke H, Murry CE. Transplantation of undifferentiated murine embryonic stem cells in the heart: teratoma formation and immune response. Faseb J. 2007; 21(7):1345-1357. [PubMed: 17284483]

73. Kehat I, Kenyagin-Karsenti D, Snir M, Segev H, Amit M, Gepstein A, Livne E, Binah O, Itskovitz-Eldor J, Gepstein L. Human embryonic stem cells can differentiate into myocytes with structural and functional properties of cardiomyocytes. J Clin Invest. 2001; 108(3):407-414. [PubMed: 11489934]

74. Laflamme MA, Chen KY, Naumova AV, Muskheli V, Fugate JA, Dupras SK, Reinecke H, Xu C, Hassanipour M, Police S, O’Sullivan C, Collins L, Chen Y, Minami E, Gill EA, Ueno S, Yuan C, Gold J, Murry CE. Cardiomyocytes derived from human embryonic stem cells in pro-survival factors enhance function of infarcted rat hearts. Nat Biotechnol. 2007; 25(9):1015-1024. These authors reported methods for guiding the differentiation of human embryonic stem cells into cardiomyocytes and showed that transplantation of these cells improved function in a rat infarct model. [PubMed: 17721512]

75. Yang L, Soonpaa MH, Adler ED, Roepke TK, Kattman SJ, Kennedy M, Henckaerts E, Bonham K, Abbott GW, Linden RM, Field LJ, Keller GM. Human cardiovascular progenitor cells develop from a KDR+ embryonic-stem-cell-derived population. Nature. 2008; 453(7194):524-528. This paper described the guided differentiation and isolation of multipotential cardiovascular progenitors from human embryonic stem cells. [PubMed: 18432194]

76. Xu XQ, Graichen R, Soo SY, Balakrishnan T, Rahmat SN, Sieh S, Tham SC, Freund C, Moore J, Mummery C, Colman A, Zweigerdt R, Davidson BP. Chemically defined medium supporting cardiomyocyte differentiation of human embryonic stem cells. Differentiation. 2008; 76(9):958970. [PubMed: 18557764]

77. Zhu WZ, Xie Y, Moyes KW, Gold JD, Askari B, Laflamme MA. Neuregulin/ErbB signaling regulates cardiac subtype specification in differentiating human embryonic stem cells. Circ Res. 2010; 107(6):776-786. [PubMed: 20671236]

78. Paige SL, Osugi T, Afanasiev OK, Pabon L, Reinecke H, Murry CE. Endogenous Wnt/betacatenin signaling is required for cardiac differentiation in human embryonic stem cells. PLoS ONE. 2010; 5(6):e11134. [PubMed: 20559569]

79. Ueno S, Weidinger G, Osugi T, Kohn AD, Golob JL, Pabon L, Reinecke H, Moon RT, Murry CE. Biphasic role for Wnt/beta-catenin signaling in cardiac specification in zebrafish and embryonic stem cells. Proc Natl Acad Sci U S A. 2007; 104(23):9685-9690. [PubMed: 17522258]

80. Bondue A, Lapouge G, Paulissen C, Semeraro C, Iacovino M, Kyba M, Blanpain C. Mesp1 acts as a master regulator of multipotent cardiovascular progenitor specification. Cell Stem Cell. 2008; 3(1):69-84. [PubMed: 18593560]

81. Wu SM, Fujiwara Y, Cibulsky SM, Clapham DE, Lien CL, Schultheiss TM, Orkin SH. Developmental origin of a bipotential myocardial and smooth muscle cell precursor in the mammalian heart. Cell. 2006; 127(6):1137-1150. [PubMed: 17123591]

82. Moretti A, Caron L, Nakano A, Lam JT, Bernshausen A, Chen Y, Qyang Y, Bu L, Sasaki M, Martin-Puig S, Sun Y, Evans SM, Laugwitz KL, Chien KR. Multipotent embryonic isl1+ progenitor cells lead to cardiac, smooth muscle, and endothelial cell diversification. Cell. 2006; 127(6):1151-1165. [PubMed: 17123592]

83. Domian IJ, Chiravuri M, van der Meer P, Feinberg AW, Shi X, Shao Y, Wu SM, Parker KK, Chien KR. Generation of functional ventricular heart muscle from mouse ventricular progenitor cells. Science. 2009; 326(5951):426-429. [PubMed: 19833966]

84. Caspi O, Huber I, Kehat I, Habib M, Arbel G, Gepstein A, Yankelson L, Aronson D, Beyar R, Gepstein L. Transplantation of human embryonic stem cell-derived cardiomyocytes improves myocardial performance in infarcted rat hearts. J Am Coll Cardiol. 2007; 50(19):1884-1893. [PubMed: 17980256] 
85. Fernandes S, Naumova AV, Zhu WZ, Laflamme MA, Gold J, Murry CE. Human embryonic stem cell-derived cardiomyocytes engraft but do not alter cardiac remodeling after chronic infarction in rats. J Mol Cell Cardiol. 2010; 49(6):941-949. [PubMed: 20854826]

86. van Laake LW, Passier R, Doevendans PA, Mummery CL. Human embryonic stem cell-derived cardiomyocytes and cardiac repair in rodents. Circ Res. 2008; 102(9):1008-1010. [PubMed: 18436793]

87. Murry CE, Kay MA, Bartosek T, Hauschka SD, Schwartz SM. Muscle differentiation during repair of myocardial necrosis in rats via gene transfer with MyoD. J Clin Invest. 1996; 98(10):2209_ 2217. [PubMed: 8941636]

88. Ieda M, Fu JD, Delgado-Olguin P, Vedantham V, Hayashi Y, Bruneau BG, Srivastava D. Direct reprogramming of fibroblasts into functional cardiomyocytes by defined factors. Cell. 2010; 142(3):375-386. In this paper, the authors reported the direct reprogramming of cardiac fibroblasts into a cardiomyocyte-like state via the forced expression of three cardiac transcription factors. [PubMed: 20691899]

89. Efe JA, Hilcove S, Kim J, Zhou H, Ouyang K, Wang G, Chen J, Ding S. Conversion of mouse fibroblasts into cardiomyocytes using a direct reprogramming strategy. Nat Cell Biol. 2011; 13(3): 215-222. [PubMed: 21278734]

90. Ratner BD, Bryant SJ. Biomaterials: where we have been and where we are going. Annu Rev Biomed Eng. 2004; 6:41-75. [PubMed: 15255762]

91. Madden LR, Mortisen DJ, Sussman EM, Dupras SK, Fugate JA, Cuy JL, Hauch KD, Laflamme MA, Murry CE, Ratner BD. Proangiogenic scaffolds as functional templates for cardiac tissue engineering. Proc Natl Acad Sci U S A. 2010; 107(34):15211-15216. [PubMed: 20696917]

92. Radisic M, Park H, Shing H, Consi T, Schoen FJ, Langer R, Freed LE, Vunjak-Novakovic G. Functional assembly of engineered myocardium by electrical stimulation of cardiac myocytes cultured on scaffolds. Proc Natl Acad Sci U S A. 2004; 101(52):18129-18134. [PubMed: 15604141]

93. Zimmermann WH, Melnychenko I, Wasmeier G, Didie M, Naito H, Nixdorff U, Hess A, Budinsky L, Brune K, Michaelis B, Dhein S, Schwoerer A, Ehmke H, Eschenhagen T. Engineered heart tissue grafts improve systolic and diastolic function in infarcted rat hearts. Nat Med. 2006; 12(4): 452-458. This paper described the formation of engineered heart tissue using neonatal rat cardiomyocytes and showed that their implantation improved electrical and mechanical function in injured hearts. [PubMed: 16582915]

94. Reinecke H, Zhang M, Bartosek T, Murry CE. Survival, integration, and differentiation of cardiomyocyte grafts: a study in normal and injured rat hearts. Circulation. 1999; 100(2):193-202. [PubMed: 10402450]

95. Stevens KR, Kreutziger KL, Dupras SK, Korte FS, Regnier M, Muskheli V, Nourse MB, Bendixen K, Reinecke H, Murry CE. Physiological function and transplantation of scaffold-free and vascularized human cardiac muscle tissue. Proc Natl Acad Sci U S A. 2009; 106(39):1656816573. [PubMed: 19805339]

96. Caspi O, Lesman A, Basevitch Y, Gepstein A, Arbel G, Habib IH, Gepstein L, Levenberg S. Tissue engineering of vascularized cardiac muscle from human embryonic stem cells. Circ Res. 2007; 100(2):263-272. [PubMed: 17218605]

97. Dvir T, Kedem A, Ruvinov E, Levy O, Freeman I, Landa N, Holbova R, Feinberg MS, Dror S, Etzion Y, Leor J, Cohen S. Prevascularization of cardiac patch on the omentum improves its therapeutic outcome. Proc Natl Acad Sci U S A. 2009; 106(35):14990-14995. [PubMed: 19706385]

98. Zakharova L, Mastroeni D, Mutlu N, Molina M, Goldman S, Diethrich E, Gaballa MA. Transplantation of cardiac progenitor cell sheet onto infarcted heart promotes cardiogenesis and improves function. Cardiovasc Res. 2010; 87(1):40-49. [PubMed: 20118202]

99. Brodsky, VYa; Chernyaev, AL.; Vasilyeva, IA. Variability of the cardiomyocyte ploidy in normal human hearts. Virchows Arch B Cell Pathol Incl Mol Pathol. 1991; 61(4):289-294. [PubMed: 1685821]

100. Rumyantsev PP, Erokhina IL, Antipanova EM, Martynova MG. DNA and sex chromatin content in nuclei of conductive system and working myocytes of normal and hypertrophied human heart. Acta Histochem Suppl. 1990; 39:225-237. [PubMed: 2150446] 


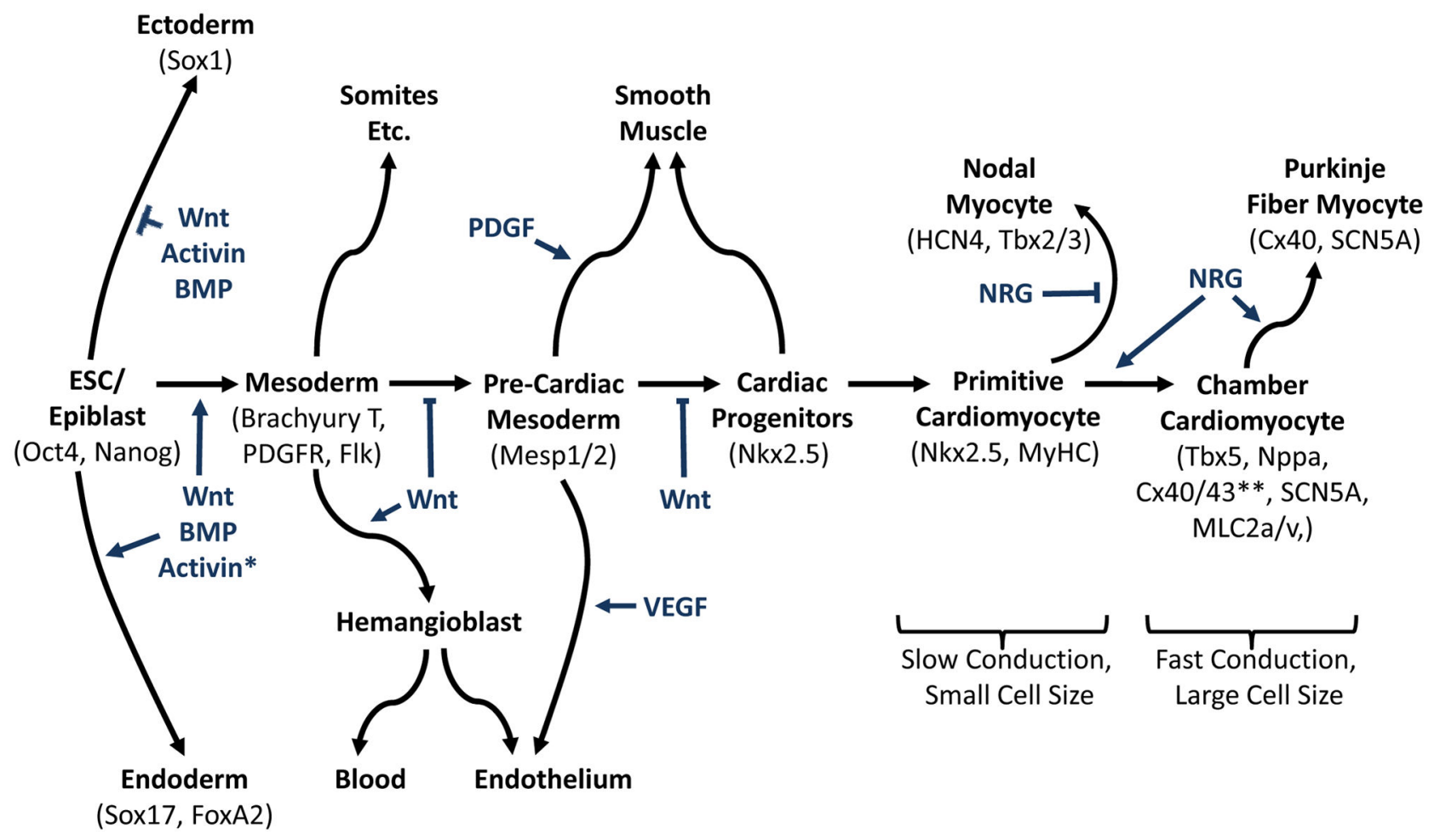

Figure 1. Cardiovascular lineages during embryonic development and embryonic stem cell differentiation

Cardiac differentiation from ESCs closely mimics cardiac development in the embryo. In either case, the specification of the cardiovascular lineages involves a transition through a sequence of increasingly restricted progenitors, proceeding from a pluripotent state to mesoderm and then to cells committed to cardiovascular fates. Growth factors that regulate fate choices are listed at branch points, and key transcription factors and surface markers for each cell state are listed under the cell types. These growth factors are useful for directing the differentiation of ESCs, while the markers are useful for purifying cells at defined developmental states. Primitive cardiomyocytes in the embryonic heart tube and nodal/ pacemaker cells exhibit slow electrical propagation and a small cell size. In contrast, the eventual specification of working atrial and ventricular cardiomyocytes is accompanied by more rapid conduction, ion channel remodeling and increased cell size. While the field has made considerable progress toward the elucidation of early events during cardiogenesis, a better understanding of how pacemaker vs. chamber-specific cardiac subtypes are formed is required for clinical applications. 
a
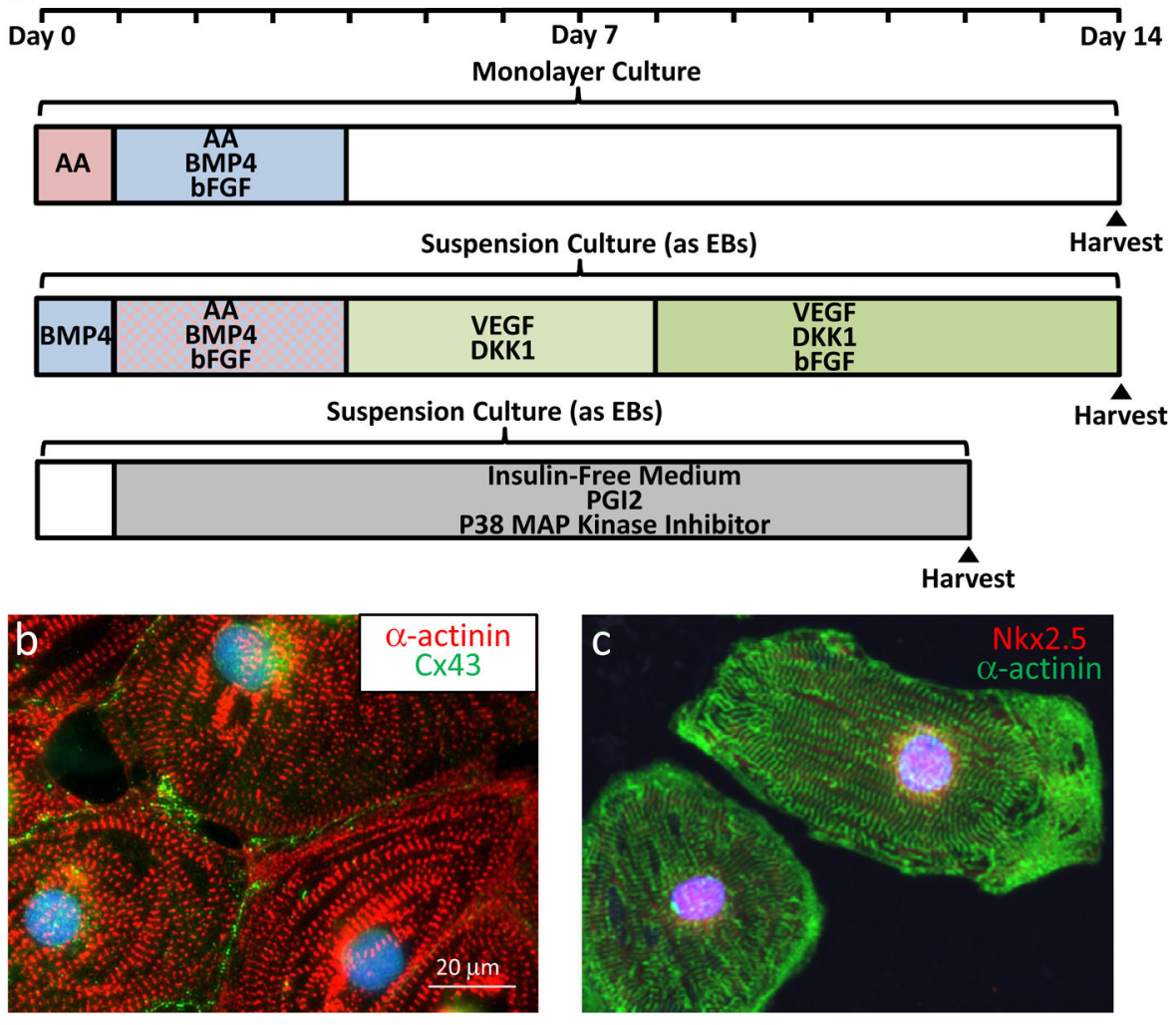

d

e
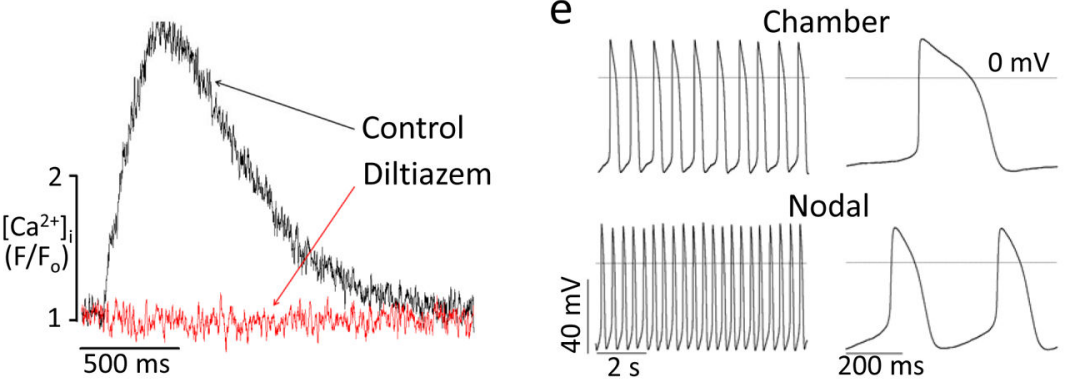

Figure 2. Guided differentiation and phenotype of cardiomyocytes from pluripotent stem cells $\boldsymbol{a}$, Selected protocols for the guided differentiation of human ESCs and iPSCs into cardiomyocytes using chemically-defined factors. The upper timeline shows a protocol from our group in which differentiating cells are serially pulsed with activin A (AA) and BMP4 under monolayer culture conditions ${ }^{74}$. The middle timeline shows a protocol from the Keller lab that involves embryoid body (EB) formation in suspension cultures and the application of multiple signaling molecules including activin A, BMP4 $4^{75}$ The lower timeline shows a protocol from Davidson and colleagues in which EBs are continuously cultured in insulinfree medium supplemented with prostaglandin $\mathrm{I} 2$ and an inhibitor of p38 MAP kinase ${ }^{76} . \boldsymbol{b}$, Representative human ESC-derived cardiomyocyte, differentiated using the monolayer protocol, immunostained for a-actinin (red) and connexin43 (Cx43; green). c, Representative human iPSC-derived cardiomyocyte, differentiated using the monolayer protocol, immunostained for a-actinin (green) and the transcription factor $\mathrm{Nkx} 2.5$ (red). $\boldsymbol{d}$, Intracellular $\left[\mathrm{Ca}^{2+}\right]$ transients in a human ESC-derived cardiomyocyte before (black) and 
after (red) application of diltiazem, an L-type $\mathrm{Ca}^{2+}$ channel blocker. Absence of $\left[\mathrm{Ca}^{2+}\right]$ transients after diltiazem treatment indicates extracellular $\left[\mathrm{Ca}^{2+}\right]$ is required to initiate intracellular $\left[\mathrm{Ca}^{2+}\right]$ release, just as in adult cardiomyocytes. $\boldsymbol{e}$, Human ESC-derived cardiomyocytes show the characteristic action potential properties of either working chamber (upper) or nodal myocytes (lower), indicating early subtype specification. 

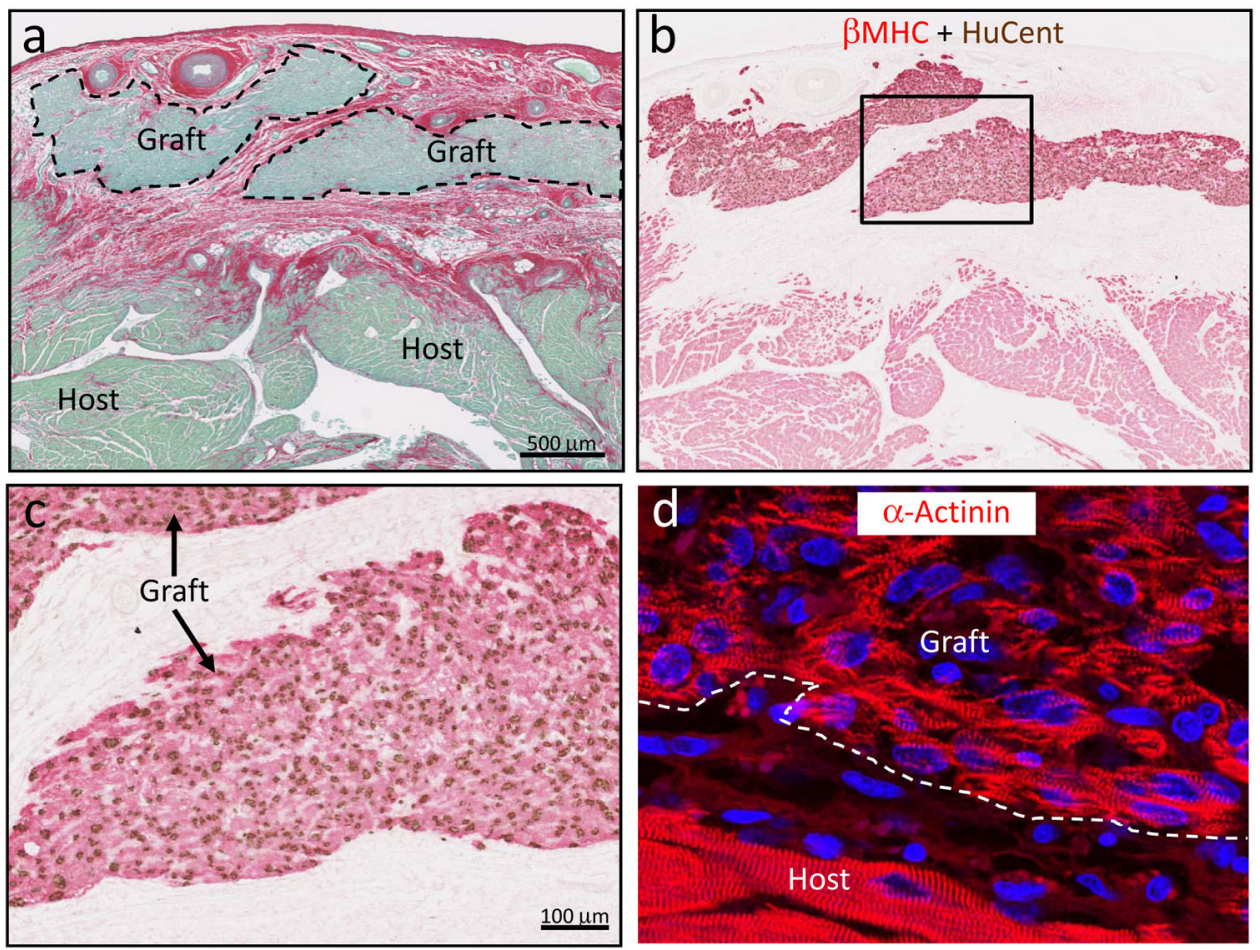

Figure 3. Grafts of human ESC-derived cardiomyocytes in the cryoinjured guinea pig heart Representative photomicrographs demonstrating substantial implants of human myocardium within the scar tissue. $\boldsymbol{a}$, By picrosirius red stain, the scar appears red and viable tissue green. Scale bar=500 $\mu \mathrm{m}$. $\boldsymbol{b}$, The human origin of the graft myocardium was confirmed in an adjacent section by combined in situ hybridization with a human-specific pan-centromeric (HuCent, brown) probe and $\beta$-myosin heavy chain ( $\beta \mathrm{MHC}$, red) immunohistochemistry. $\boldsymbol{c}$, Inset from panel $b$ at higher magnification. Note the nuclear localization of the HuCent signal, confirming human origin of these cells. $\boldsymbol{d}$, Immunostaining for a-actinin highlights the sarcomeric organization of the graft myocytes. 